\title{
Field Operations Program Toyota PRIUS Hybrid Electric Vehicle Performance Characterization Report
}

J. Francfort

N. Nguyen

J. Phung

J. Smith

M. Wehrey

December 2001

Idaho National Engineering and Environmental Laboratory Bechtel BWXT Idaho, LLC 


\title{
Field Operations Program Toyota PRIUS Hybrid Electric Vehicle Performance Characterization Report
}

\author{
J. Francfort ${ }^{1}$ \\ N. Nguyen ${ }^{2}$ \\ J. Phung ${ }^{2}$ \\ J. Smith ${ }^{2}$ \\ M. Wehrey ${ }^{2}$
}

Published December 2001

Idaho National Engineering and Environmental Laboratory Automotive Systems and Technology Department Idaho Falls, Idaho 83415

Prepared for the

U.S. Department of Energy

Assistant Secretary for Energy Efficiency and Renewable Energy

Under DOE Idaho Operations Office

Contract No. DE-AC07-99ID13727

${ }^{1}$ INEEL/Bechtel BWXT Idaho, LLC.

${ }^{2}$ Southern California Edison 


\section{Disclaimer}

This document highlights work sponsored by agencies of the U.S. Government. Neither the U.S. Government nor any agency thereof, nor any of their employees, makes any warranty, express or implied, or assumes any legal liability or responsibility for the accuracy, completeness, or usefulness of any information, apparatus, product, or process disclosed, or represents that its use would not infringe privately owned rights. Reference herein to any specific commercial product, process, or service by trade name, trademark, manufacturer, or otherwise does not necessarily constitute or imply its endorsement, recommendation, or favoring by the U.S. Government or any agency thereof. The views and opinions of authors expressed herein do not necessarily state or reflect those of the U.S. Government or any agency thereof. 


\section{EXECUTIVE SUMMARY}

The U.S. Department of Energy's Field Operations Program evaluates advanced technology vehicles in real-world applications and environments. Advanced technology vehicles include pure electric, hybrid electric, hydrogen, and other vehicles that use emerging technologies such as fuel cells. Information generated by the Program is targeted to fleet managers and others considering the deployment of advanced technology vehicles. As part of the above activities, the Field Operations Program has initiated the testing of the Toyota Prius hybrid electric vehicle (HEV), a technology increasingly being considered for use in fleet applications. This report describes the Pomona Loop testing of the Prius, providing not only initial operational and performance information, but also a better understanding of HEV testing issues. The Pomona Loop testing includes both Urban and Freeway drive cycles, each conducted at four operating scenarios that mix minimum and maximum payloads with different auxiliary (e.g., lights, air conditioning) load levels.

The Prius is powered by a 70-hp, 1.5-liter, 4-cylinder gasoline engine and a 44-hp electric motor. The Prius also has a 274-volt battery comprising 228 1.2-volt cells.

The Prius exhibited test results of 35 to 58 mpg during the Urban Loop testing; the EPA estimate for city driving is $52 \mathrm{mpg}$. During the Freeway Loop testing, the Prius got 39 to $46 \mathrm{mpg}$; the EPA estimate for highway driving is $45 \mathrm{mpg}$. Even though the EPA tests are conducted on a dynamometer and the Pomona Loop tests are conducted as on-road driving tests, when tested with a minimum payload and no auxiliary loads, the mpg test results are the same for the Freeway Loop testing and the EPA highway testing. Under the same operating scenario, the Urban Loop results are $4 \mathrm{mpg}$ higher than the EPA estimate for city driving.

The Pomona Loop testing of the Prius also demonstrated the difficulty of measuring fuel use. Unlike electric vehicles, where a $\mathrm{kWh}$ or amp-hour meter can accurately measure electron flows, the HEV's fuel use is determined by measuring how much gasoline was used; so a void must now be accurately measured. One option is to apply a known amount of fuel to the vehicle and run it until it stops. However, rarely will a perfectly uniform amount of fuel remain and even more rarely will the vehicle run out of fuel where it started, so this method is not practical for onroad testing.

Another issue is that variables such as driver behavior (the "lead" foot), the use of air conditioning and other auxiliary loads, or the type of driving cycle used can result in significant energy efficiency variations. The eight individual Urban Loop test results ranged from 35.3 to $54.5 \mathrm{mpg}$, a $54 \%$ differential.

The Prius testing not only provided an initial performance benchmark for the Prius but also highlighted HEV-specific testing issues. These will be used to prepare for expanded HEV testing, and to ensure accurate fuel-use measurements are taken in applications that are both meaningful and applicable to fleet managers. 


\section{CONTENTS}

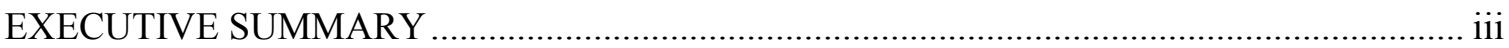

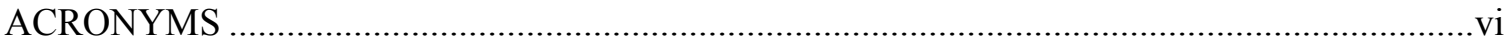

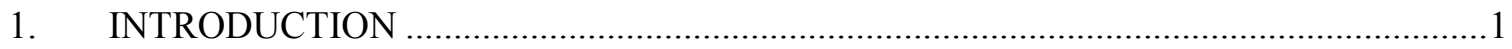

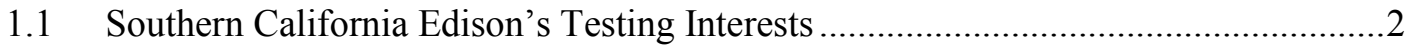

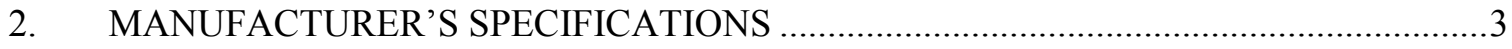

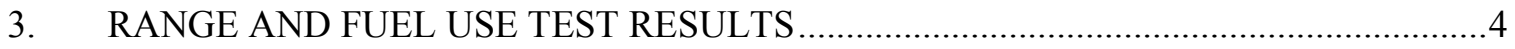

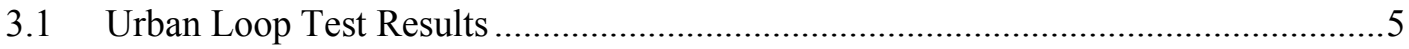

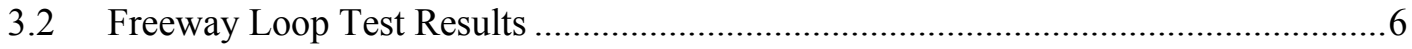

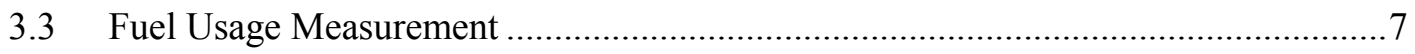

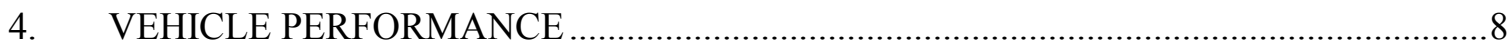

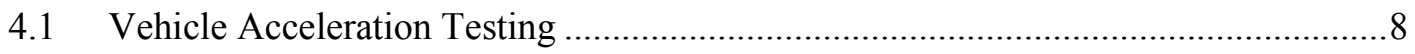

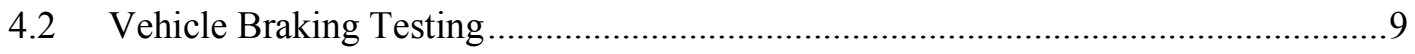

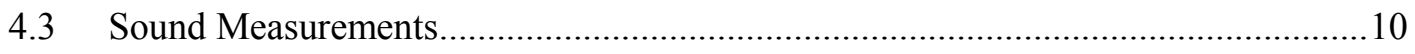

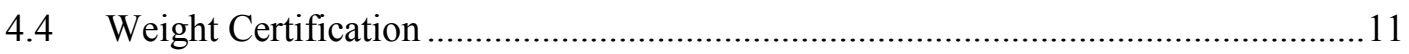

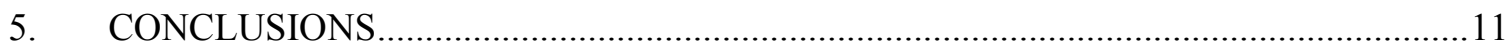

FIGURES

1. Average mph for each operating scenario used for the Urban and Freeway Pomona Loops......7

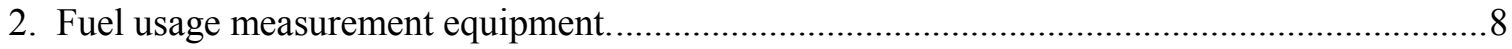

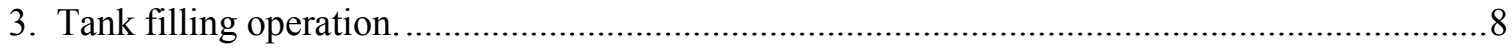

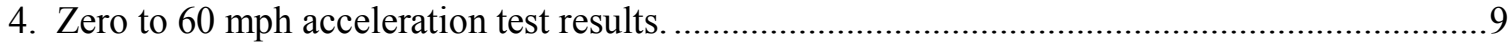

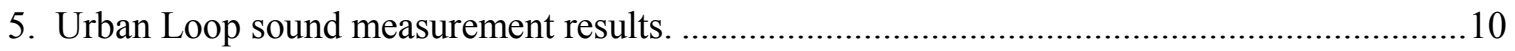

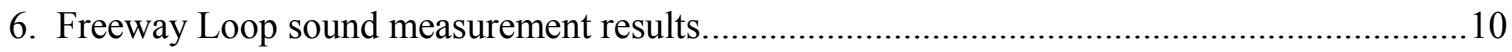




\section{TABLES}

1. Toyota Prius manufacturer specifications. Source - http://prius.toyota.com/details/specs.html ..3

2. Pomona Loop operating scenarios for test vehicles. .............................................................

3. Toyota Prius miles driven and fuel use results from the Urban Loop testing. ...........................5

4. Toyota Prius miles driven and fuel use results from the Freeway Loop testing........................6

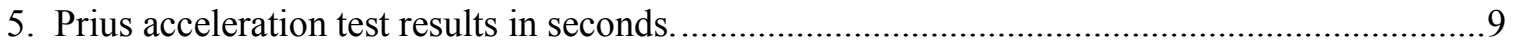

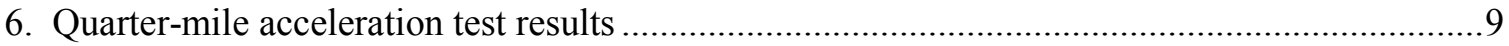

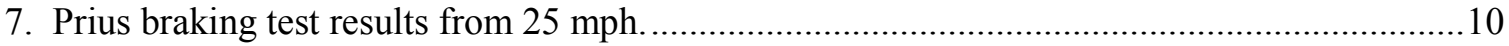

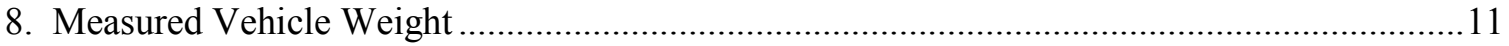




\section{ACRONYMS}

$\begin{array}{ll}\text { DOE } & \text { U.S. Department of Energy } \\ \text { EV } & \text { Electric Vehicle } \\ \text { EVTC } & \text { Electric Vehicle Technical Center } \\ \text { HEV } & \text { Hybrid Electric Vehicle } \\ \text { INEEL } & \text { Idaho National Engineering and Environmental Laboratory } \\ \text { kWh } & \text { kilowatt-hour } \\ \text { MPG } & \text { Miles per Gallon } \\ \text { NiMH } & \text { Nickel metal hydride (battery) } \\ \text { QVTs } & \text { Qualified Vehicle Testers } \\ \text { SCE } & \text { Southern California Edison Company } \\ \text { SOC } & \text { state-of-charge }\end{array}$




\section{Field Operations Program Toyota PRIUS Hybrid Electric Vehicle Performance Characterization Report}

\section{INTRODUCTION}

The Field Operations Program provides fleet managers and other potential advanced technology vehicle (ATV) users with accurate and unbiased information on vehicle performance. This allows the purchaser to make informed decisions about acquiring and operating ATVs. Vehicle information is obtained by testing ATVs in conjunction with industry partners and disseminating the testing results. The ATVs are tested using three methods - Baseline Performance Testing, Accelerated Reliability Testing, and Fleet Testing. The testing results are disseminated via the Program's Website in the form of vehicle fact sheets, summary reports, and survey results (http://ev.inel.gov/fop). Additional information on the Website includes testing specifications and procedures as well as general information about ATVs, such as how they work and their histories.

The Field Operations Program signed a 5-year testing agreement in 1999 with the following group of Qualified Vehicle Testers (QVTs):

- Electric Transportation Applications (lead partner)

- American Red Cross.

- Arizona Public Service

- Bank One of Arizona

- Potomac Electric Power Company

- Salt River Project

- Southern California Edison

- Southwest Airlines

- Virginia Power

As part of the Field Operations Program testing activities, Southern California Edison (SCE) performed Pomona Loop testing on a Toyota Prius hybrid electric vehicle (HEV).

The Pomona Loop testing of the Prius was conducted not only to gather its operational and performance information, but also to better understand HEV testing issues. For instance, what testing variables are unique to HEVs and can these variables significantly affect the accuracy of the test results? Another question is how should HEVs be tested so the results are meaningful to fleet managers and other potential HEV users? Informal conversations with other HEV testers indicate that some test methods do not always accurately reflect the performance of HEVs when they are used in fleet applications. In addition, there are Websites that post very high miles per gallon (mpg) results obtained by HEV drivers. Only when you read the "fine print" do you discover that these drivers employ behaviors that include "drafting" 3 feet from the back ends of tractor-trailers. Other such behavior associated with very high mpg includes limiting highway speeds to 50-55 $\mathrm{mph}$ when the speed limit is $65 \mathrm{mph}$ or higher. These unsafe driving behaviors will hopefully not be encouraged by fleet managers nor practiced by fleet drivers. 
Program personnel and the testing partners recognized that new test procedures and controls could be required for HEV testing. Because they wanted to determine whether past electric vehicle (EV) testing experience was applicable to HEV testing and not be presumptuous that they fully understood all of the HEV testing issues, they decided to apply a lessons-learned approach to the first HEV tests.

For example, when EVs are range tested, the distance traveled per charge was rarely greater than 100 miles and the energy used was usually 20 to $30 \mathrm{kWh}$. Electric energy use is easy to measure with $\mathrm{kWh}$ or amp meters, and the mathematics of distance traveled versus energy units used make range calculations very accurate. However, when testing gasoline use in HEVs, more miles must be accumulated to accurately measure either energy use per distance traveled or distance traveled per energy unit.

Pomona Loop testing is a relatively fast and inexpensive method to identify these and other issues such as the significant variations in fuel consumption that can occur in HEVs when driver behavior is variable. This can include not only the aggressiveness in how the test driver drives the $\mathrm{HEV}$, but also what on-board vehicle options are turned on during the drive. For instance, air conditioning can have a significant energy use impact, especially with the smaller gasoline engines used in HEVs.

To more fully understand the above and other issues, as well as to prepare for more complex (and expensive) testing, the Field Operations Program partnered with SCE to Pomona Loop test the Prius.

SCE also has their own organizational interests that compelled them to want to test the Prius. These are briefly discussed below.

The Prius testing results discussed in this report are based on the SCE Prius testing report (TC-01-138-TR02). This report summarizes the results.

\subsection{Southern California Edison's Testing Interests}

Over the years, new technologies have evolved that promise to have a significant impact in the transportation industry. One such technology is the hybrid power train. It is important that these early market entrants be evaluated and understood in terms of performance, energy efficiency, and emissions. Once different models have been tested, an evaluation of the benefits of the different hybrid configurations, including plug-in hybrids, will be possible. To this end, SCE partnered with the Field Operations Program to conduct a performance characterization of a Toyota Prius.

The purpose of SCE's evaluation of EVs, HEVs, EV chargers, batteries, and related items is to support their safe and efficient use and to minimize potential utility system impacts. The following facts support this purpose:

- $\quad$ As a fleet operator and an electric utility, SCE uses EVs to conduct business.

- $\quad$ SCE must evaluate EVs, HEVs, batteries, and charging equipment in order to make informed purchase decisions.

- $\quad$ SCE must determine if there are any safety issues with EV equipment and their usage. 
- SCE has a responsibility to educate and advise its customers about the efficient and safe operation of EVs and HEVs.

Tests performed were: weight certification, range, fuel efficiency, performance (acceleration, maximum speed, and braking), and sound measurements. They were conducted at SCE's Electric Vehicle Technical Center (EVTC) and on the Urban and the Freeway Pomona Loops. Testing was conducted in accordance with the SCE HEV test procedure.

\section{MANUFACTURER'S SPECIFICATIONS}

Table 1. Toyota Prius manufacturer specifications. ${ }^{a}$

Gasoline Engine
Type:
Displacement (cc)
Horsepower @ rpm
Torque @ rpm
Compression Ratio
Valvetrain:
Fuel System:
Ignition System:
Emission Rating:
Electric Motor/ Generator
Motor Type
Power Output
Electric Power Storage
Battery Type
Output
Drivetrain
Type:
Transmission:
Body/Suspension/Chassis
Body Type:
Front Suspension:
Rear Suspension:
Electric Power Steering (EPS)
Turning Diameter, Curb-to-Curb (ft.)
Power-Assisted Ventilated Front Disc/Rear
Drum
4-Wheel Anti-Lock Braking System (ABS)
Wheels:
Tires:
Interior Dimensions
Head room (in., front/rear)
Leg room (in., front/rear)
Shoulder Room (in., front/rear)
Hip room (in., front/rear)
Cargo Volume (cu. ft.)
Passenger Volume (cu. ft.)
Exterior Dimensions
The

Aluminum double overhead cam (DOHC)

1497

$70 @ 4500$

$82 @ 4200$

13.0:1

16-Valve with Variable Valve Timing with intelligence (VVT-i)

Multi-Point EFI w/ Electronic Throttle Control

System w/ Intelligence (ETCS-i)

Electronic w/ Toyota Direct Ignition system (TDI)

Super Ultra Low Emission Vehicle (SULEV)

Permanent Magnet

33 kW/44hp@1040 - 5600 rpm

Sealed Nickel-Metal Hydride (NiMH)

273.6 V (228 1.2-V Cells)

Front-Wheel Drive

Electronically Controlled CVT

Aluminum monocoque

MacPherson Strut w/ stabilizer bar

Torsion Beam w/ stabilizer bar

Rack-and-Pinion w/ electric power-assist

31.6

14-in. Alloy

P175/65 R14 Low Rolling-Resistance

$38.8 / 37.1$

$41.2 / 35.4$

$52.8 / 52.2$

$50.7 / 51.9$

11.8

88.6 


\begin{tabular}{ll}
\hline Wheelbase (in.) & 100.4 \\
Length (in.) & 169.6 \\
Height (in.) & 57.6 \\
Width (in.) & 66.7 \\
Track (in., front/rear) & $58.1 / 58.2$ \\
Curb Weight (lbs.) & 2765 \\
& \\
EPA Mileage Estimates $\dagger \dagger /$ Fuel Capacity & $52 / 45 / 48$ \\
City/Highway/Combined & 11.9 \\
Fuel (gal.) & Regular Unleaded \\
Fuel Required & \\
†† Final EPA mileage estimate. Actual mileage may vary. \\
\hline \multicolumn{2}{l}{ a. Source - } \\
http://prius.toyota.com/details/specs.html
\end{tabular}

\section{RANGE AND FUEL USE TEST RESULTS}

The Pomona Loop Testing consists of two types of on-road drive cycles:

1. The Urban Loop is 19.3 miles long with approximately 50 stop signs and traffic lights, and the elevation ranges from about 900 to 1,500 feet above sea-level (Appendix A). The Urban Loop is located in the greater Pomona, California area and it consists of city and residential area streets.

2. The Freeway Loop is 37.2 miles long with elevation ranges from about 700 to 1,150 feet above sea-level (Appendix A). The Freeway Loop is located in the much greater Pomona, California area and it consists of Southern California freeways.

Four vehicle-operating scenarios are used for each of the Pomona Loops, including operating the test vehicles with minimum or maximum payloads and either no auxiliary or auxiliary loads (Table 2). The Prius was tested twice at each of the four operating scenarios for both the Urban and Freeway Loops, so that a total of 16 drive cycles were performed.

Table 2. Pomona Loop operating scenarios for test vehicles.

\begin{tabular}{ll}
\hline \multicolumn{2}{l}{ Pomona Urban Loop Vehicle Operating Scenarios } \\
\hline UR-1 & Urban Range Test, Min Payload, No Auxiliary Loads \\
UR-2 & Urban Range Test, Min Payload, A/C on High, Headlights on Low, Radio On \\
UR-3 & Urban Range Test, Max Payload, No Auxiliary Loads \\
UR-4 & Urban Range Test, Max Payload, A/C on High, Headlights on Low, Radio On \\
Pomona Freeway Loop Vehicle Operating Scenarios \\
FW-1 & Freeway Range Test, Min Payload, No Auxiliary Loads \\
FW-2 & Freeway Range Test, Min Payload, A/C on High, Headlights on Low, Radio On \\
FW-3 & Freeway Range Test, Max Payload, No Auxiliary Loads \\
FW-4 & Freeway Range Test, Max Payload, A/C on High, Headlights on Low, Radio On \\
\hline
\end{tabular}


For a full discussion of the Urban and Freeway Pomona Loop testing, the Southern California Edison Pomona Loop Test Procedures Report can be accessed at the following address http://ev.inel.gov/fop

\subsection{Urban Loop Test Results}

The Prius was tested twice for each of four operating scenarios on the Urban Pomona Loop (Table 3). For urban driving with a minimum payload and no auxiliaries used (UR-1), the average fuel economy was $55.6 \mathrm{mpg}$. With a minimum payload and the auxiliary loads turned on (UR-2), the fuel economy dropped to an average of $49.5 \mathrm{mpg}$. With the maximum payload and no auxiliaries on (UR-3), the fuel economy was $47.5 \mathrm{mpg}$. With the maximum payload and the auxiliary loads turned on (UR-4), the fuel economy dropped to $35.7 \mathrm{mpg}$. It should be noted that while the driver was not supposed to play the radio during the no-auxiliary load tests, the radio was played during all of the mileage tests, including the no-auxiliary load tests (Loops UR-1 and UR-3).

Table 3. Toyota Prius Urban Loop testing results.

\begin{tabular}{ccccccc}
\hline $\begin{array}{c}\text { Drive } \\
\text { Cycle }\end{array}$ & Test Date & $\begin{array}{c}\text { Average Ambient } \\
\text { Temp (F) }\end{array}$ & $\begin{array}{c}\text { Total fuel } \\
\text { usage (gal) }\end{array}$ & $\begin{array}{c}\text { Miles } \\
\text { driven }\end{array}$ & $\begin{array}{c}\text { Calculated } \\
\text { MPG }\end{array}$ & $\begin{array}{c}\text { Manufacturer } \\
\text { MPG }^{1}\end{array}$ \\
\hline UR-1 & $07 / 31 / 01$ & 79.0 & 1.76 & 101.3 & 57.6 & 54.4 \\
UR-1 & $08 / 22 / 01$ & 75.0 & 1.89 & 101.5 & 53.7 & 54.0 \\
UR-2 & $08 / 01 / 01$ & 79.0 & 1.99 & 102.5 & 51.4 & 52.4 \\
UR-2 & $08 / 20 / 01$ & 85.0 & 2.15 & 102.3 & 47.6 & 43.5 \\
UR-3 & $08 / 07 / 01$ & 90.0 & 2.15 & 103.1 & 47.9 & 49.1 \\
UR-3 & $08 / 15 / 01$ & 100.0 & 2.17 & 102.1 & 47.1 & 47.8 \\
UR-4 & $08 / 09 / 01$ & 84.0 & 2.91 & 102.2 & 35.2 & 35.3 \\
UR-4 & $08 / 14 / 01$ & 92.0 & 2.86 & 103.9 & 36.3 & 36.9 \\
\hline
\end{tabular}

${ }^{1}$ Fuel Economy Meter MPG is average of 21 readings.

The estimated range calculation is based on the nominal 11.9 gallon fuel tank and the above testing results. The average estimated ranges are listed by operating scenarios:

- UR-1, minimum payload and no auxiliaries - 662 miles

- $\quad$ UR-2, minimum payload and auxiliaries on - 589 miles

- $\quad$ UR-3, maximum payload and no auxiliaries - 565 miles

- UR-4, maximum payload and auxiliaries - 425 miles

The total mileage driven during the eight urban drive cycles (four types of urban tests, each driven twice) was 818.9 miles and the total fuel used was 17.88 gallons. Therefore, the overall fuel economy during the eight urban drive cycles was $45.8 \mathrm{mpg}$, and based on the 11.9-gallon fuel tank, the average range would be 545 miles. 


\subsection{Freeway Loop Test Results}

The Prius was also tested twice for each of the four operating scenarios on the Freeway Pomona Loop (Table 4). For freeway driving with a minimum payload and no auxiliaries used (FW-1), the average fuel economy was $45.4 \mathrm{mpg}$. With a minimum payload and the auxiliaries turned on (FW-2), the fuel economy dropped to an average of $42.6 \mathrm{mpg}$. With maximum payload and no auxiliaries on (FW-3), the fuel economy was $44.5 \mathrm{mpg}$. Again, with maximum payload and the auxiliary load on (FW-4), the fuel economy dropped to $40.0 \mathrm{mpg}$. It should be noted that while the driver was not supposed to play the radio during the no-auxiliary load tests, the radio was played during all of the mileage tests, including the no-auxiliary load tests (Loops FW-1 and FW-3).

Table 4. Toyota Prius miles driven and fuel use results from the Freeway Loop testing.

\begin{tabular}{ccccccc}
\hline $\begin{array}{c}\text { Drive } \\
\text { Cycle }\end{array}$ & Test Date & $\begin{array}{c}\text { Average Ambient } \\
\text { Temp }(\mathrm{F})\end{array}$ & $\begin{array}{c}\text { Total fuel } \\
\text { usage (gal) }\end{array}$ & $\begin{array}{c}\text { Miles } \\
\text { driven }\end{array}$ & $\begin{array}{c}\text { Calculated } \\
\text { MPG }\end{array}$ & $\begin{array}{c}\text { Manufacturer } \\
\text { MPG }^{1}\end{array}$ \\
\hline FW-1 & $08 / 02 / 01$ & 79.5 & 2.28 & 103.2 & 45.2 & 47.4 \\
FW-1 & $08 / 16 / 01$ & 87.0 & 2.22 & 100.9 & 45.5 & 51.8 \\
FW-2 & $08 / 03 / 01$ & 79.0 & 2.52 & 106.5 & 42.3 & 43.1 \\
FW-2 & $08 / 21 / 01$ & 78.0 & 2.37 & 102.0 & 42.9 & 41.5 \\
FW-3 & $08 / 06 / 01$ & 89.0 & 2.33 & 104.2 & 44.8 & 44.4 \\
FW-3 & $08 / 10 / 01$ & 83.0 & 2.37 & 104.8 & 44.2 & 46.1 \\
FW-4 & $08 / 08 / 01$ & 89.0 & 2.54 & 103.5 & 40.8 & 42.7 \\
FW-4 & $08 / 13 / 01$ & 87.0 & 2.58 & 101.0 & 39.1 & 41.6 \\
\hline
\end{tabular}

${ }^{1}$ Fuel Economy Meter MPG is average of 21 readings.

The estimated range calculation was based on the 11.9-gallon fuel tank and the above testing results. The average estimated freeway ranges are listed by operating scenarios:

- $\quad \mathrm{FW}-1$, minimum payload and no auxiliaries - 540 miles

- $\quad$ FW-2, minimum payload and auxiliaries on - 507 miles

- $\quad$ FW-3, maximum payload and no auxiliaries -530 miles

- $\quad$ FW-4, maximum payload and auxiliaries -476 miles.

The total mileage driven during the eight freeway drive cycles (four types of freeway tests, each driven twice) was 826.1 miles and the total fuel used was 19.21 gallons. Therefore, the overall fuel economy during the eight freeway drive cycles was $43.0 \mathrm{mpg}$, and based on the 11.9 gallon fuel tank, the average range was 512 miles.

The overall fuel use for all 16 tests averaged 43 mpg (UR\&FW Average in Figure 1). Figure 1 also shows the average mpg results for the two tests performed for each operating scenario as well as the average mpg results for all eight urban tests (UR-Average) and all eight freeway tests (FW-Average). (See Table 2 for an explanation of the operating scenarios). 


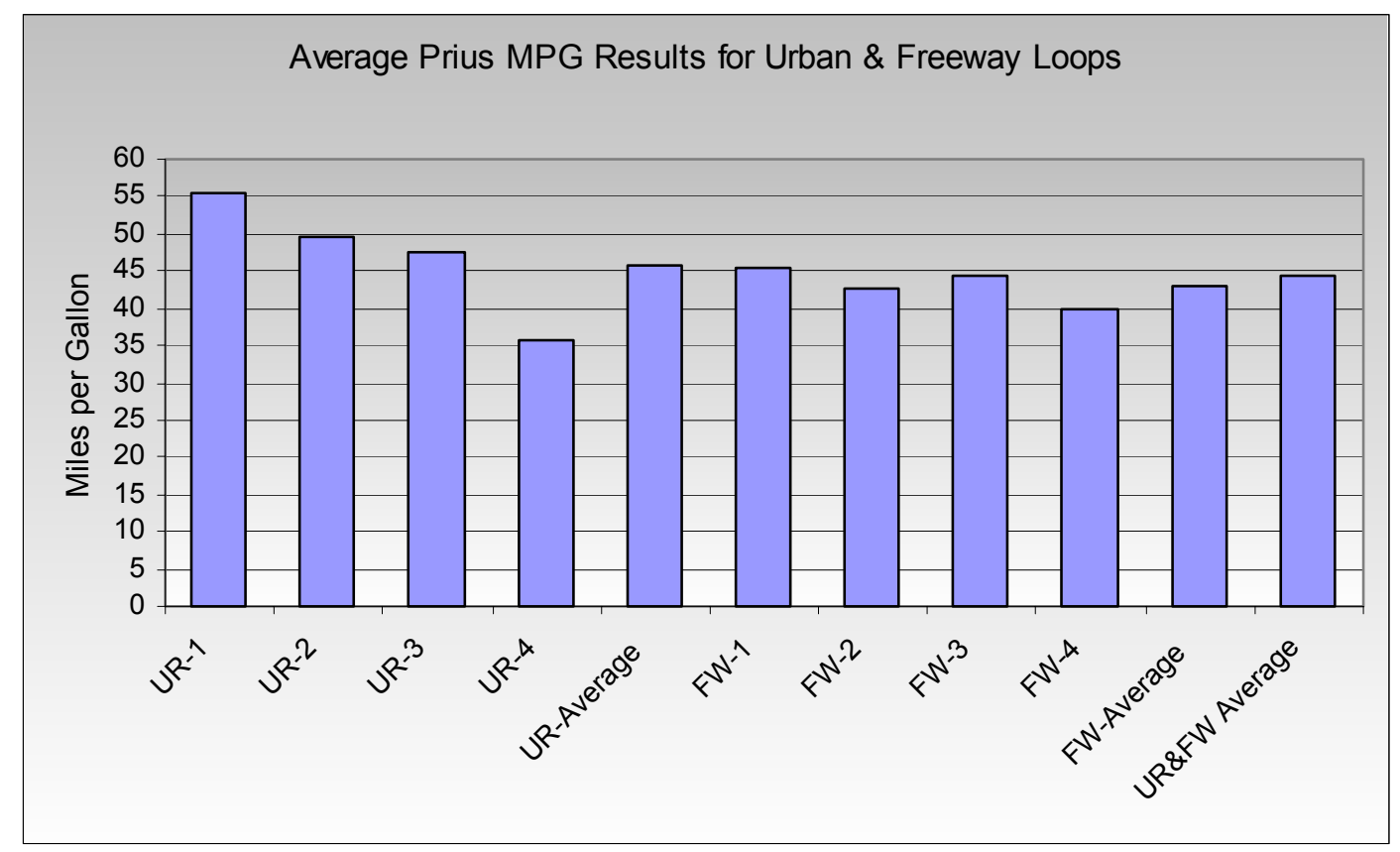

Figure 1. Average mph for each operating scenario used for the Urban and Freeway Pomona Loops.

\subsection{Fuel Usage Measurement}

As mentioned in the introduction, this initial round of Pomona Loop HEV Testing was not envisioned to be the most rigorous of quantitative tests of fuel use. The Prius was leased, which limited the fuel use measurement options to nonintrusive methods both because of the lease agreement and the desire to minimize testing (and vehicle repair) costs. Given these constraints, three low-cost, nonintrusive (or quasi-nonintrusive) fuel use measurement methods were considered, two of which were discarded.

One method would have relied on gas pump readings to determine the quantity of fuel used for a given test. When the vehicle tank was refilled, the "first click" of the pump nozzle would be accepted as indication of a "full" tank and the fuel quantity displayed by the pump would be read. However, the variability of this method is well known to anyone that has successfully added gasoline after the first "click".

To improve the accuracy of the tests, a second method was considered and attempted. It relied on draining the vehicle tank with the fuel system pump (by temporarily disconnecting the fuel supply line and activating the pump with the "ignition key on") and filling it with a known quantity of fuel. Measuring the make-up fuel would have yielded fuel usage. Unfortunately, it was not possible to get a consistent "empty tank" condition; successive reactivation of the fuel pump always drained an additional amount of fuel.

The third method relied on carefully refilling the vehicle tank in the EVTC lab, early in the morning (to minimize ambient temperature swings and gasoline expansion from movement), before each drive cycle with a lab-quality graduated cylinder (Figures 2 and 3). A notch in the tank filler tube was giving the necessary liquid level reference. Milliliter numbers were converted to gallons and logged (Tables 5 and 6). This method was used and it met the criteria of being nonintrusive and low cost, while elucidating HEV testing variables and issues. 
Figure 2. Fuel usage measurement equipment.

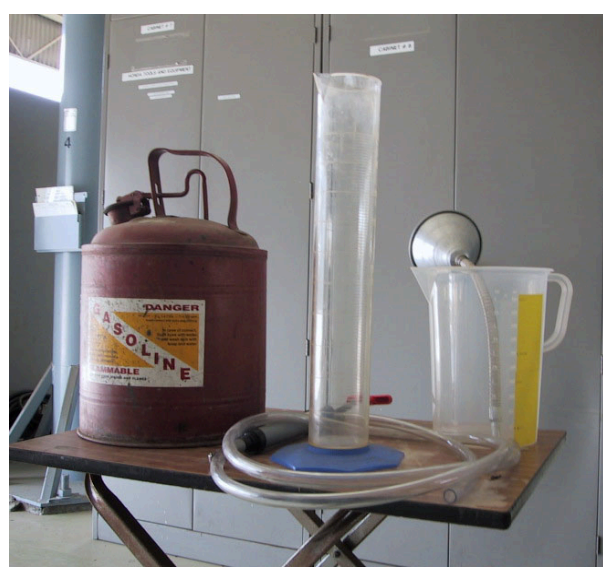

Figure 3. Tank filling operation.

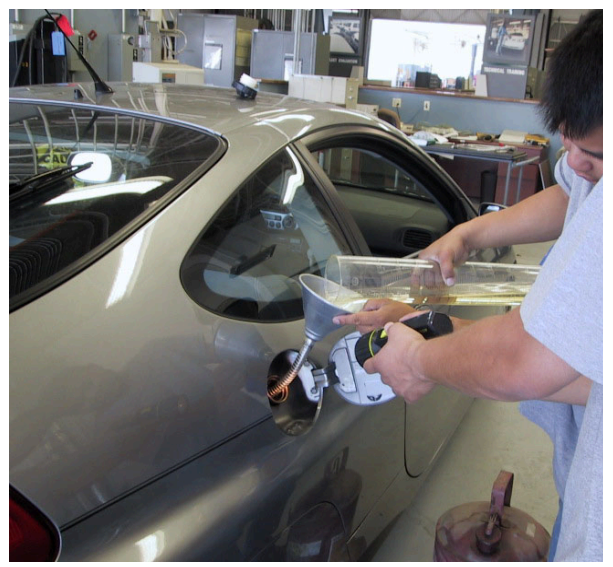

\section{VEHICLE PERFORMANCE TESTS}

Performance testing was conducted at the Los Angeles County Fairplex drag strip in Pomona, California on August 27, 2001. The tests were started at 11:00 AM and completed by 12:30 PM. The ambient temperature was $92-93^{\circ} \mathrm{F}$ and wind speeds of $3-5 \mathrm{mph}$ from the Northwest were present. Tire pressures were 34 psi (front wheels) and 36 psi (rear wheels).

\subsection{Vehicle Acceleration Testing}

Table 5 shows the results from the acceleration tests. The computer-generated average acceleration time for $0-30 \mathrm{mph}$ was 4.5 seconds and for $0-60 \mathrm{mph}$ it was 13.1 seconds. The $30-$ $55 \mathrm{mph}$ accelerations were hand timed; the average time was 7.0 seconds. One of the 0 to $60 \mathrm{mph}$ acceleration tests is shown Figure 4. Table 6 shows the results of quarter-mile acceleration results. The average time was 19.4 seconds, with an average speed of $74.1 \mathrm{mph}$. In separate tests, the maximum recorded speeds were $87.9 \mathrm{mph}$ (southbound) and $82.8 \mathrm{mph}$ (northbound). 
Table 5. Prius acceleration test results in seconds.

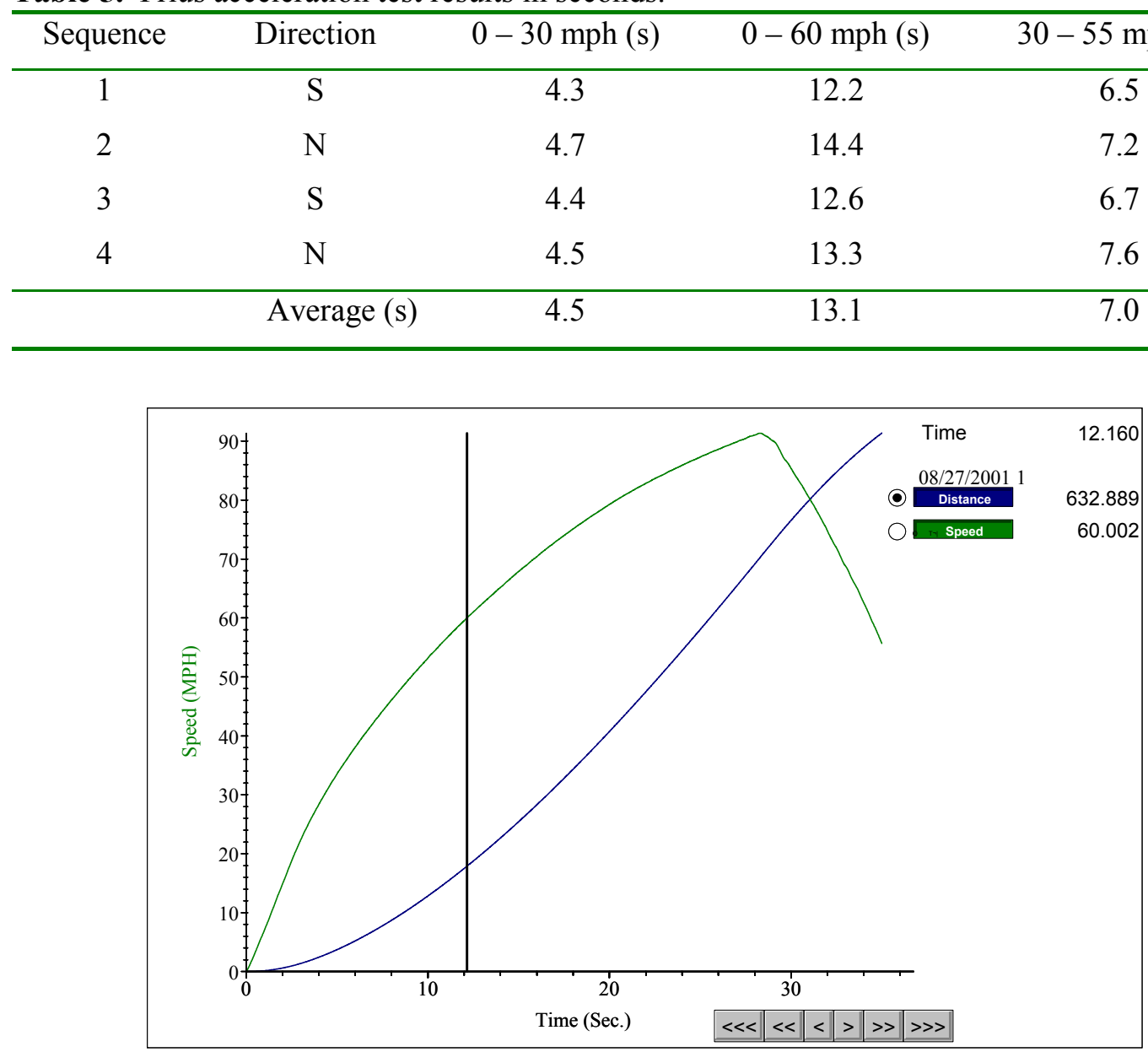

Figure 4. Zero to $60 \mathrm{mph}$ acceleration test results.

Table 6. Quarter-mile acceleration test results

\begin{tabular}{cccc}
\hline Sequence & Direction & Time (seconds) & Speed (mph) \\
\hline 1 & $\mathrm{~S}$ & 18.9 & 77.1 \\
2 & $\mathrm{~N}$ & 20.0 & 70.5 \\
3 & $\mathrm{~S}$ & 19.2 & 75.9 \\
4 & $\mathrm{~N}$ & 19.6 & 72.8 \\
\hline & Average & 19.4 & 74.1 \\
\hline
\end{tabular}

\subsection{Vehicle Braking Testing}

Table 7 shows the results of the 25 -mph braking tests. The results were obtained with a Vericom 2000 performance computer. The average stopping distance adjusted for $25 \mathrm{mph}$ was 27.16 feet. 
Table 7. Prius braking test results from $25 \mathrm{mph}$.

\begin{tabular}{ccllll}
\hline Sequence & Direction & Speed $(\mathrm{mph})$ & Time (seconds) & $\begin{array}{l}\text { Distance } \\
(\text { feet })\end{array}$ & $\begin{array}{l}25 \text { mph Adjusted } \\
\text { Distance (ft) }\end{array}$ \\
\hline 1 & $\mathrm{~S}$ & 28.41 & 2.09 & 35.55 & 25.722 \\
2 & $\mathrm{~N}$ & 25.91 & 2.08 & 35.44 & 32.714 \\
3 & $\mathrm{~S}$ & 29.16 & 1.90 & 34.90 & 24.139 \\
4 & $\mathrm{~N}$ & 26.93 & 1.81 & 31.01 & 26.066 \\
\hline
\end{tabular}

\subsection{Sound Measurements}

These measurements were made with a Sound Level Meter placed at head level in the front passenger seat area. The sound tests were conducted for approximately 47 minutes during the Urban Loop (Figure 5) and 33 minutes during the Freeway Loop (Figure 6). The sound averaged 60 decibels during the Urban loop and between 65 and 70 decibels during the Freeway Loop.

Figure 5. Urban Loop sound measurement results.

Figure 6. Freeway Loop sound measurement results.
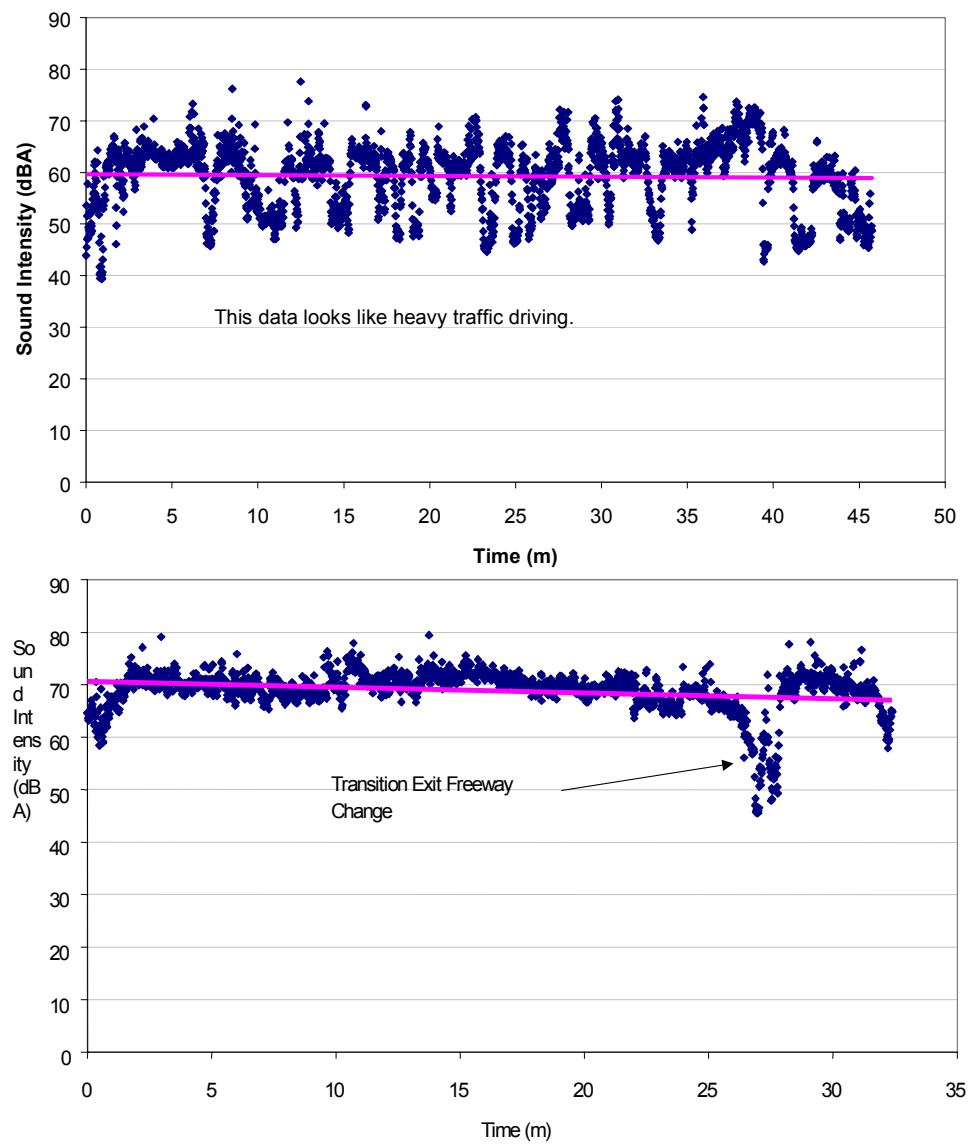


\subsection{Weight Certification}

When weighed at a certified scale, the Prius was found to have a total available payload of 885 pounds (Table 8 ).

Table 8. Measured vehicle weight.

\begin{tabular}{lccc}
\hline & Front Axle & Rear Axle & Total Weight \\
\hline Sticker GVWR (lb) & 1,970 & 1,685 & 3,655 \\
Measured Weight (lb) & 1,670 & 1,100 & 2,770 \\
Available Payload (lb) & 300 & 585 & 885 \\
\hline
\end{tabular}

\section{CONCLUSIONS}

- The Pomona Urban Loop test most similar to the EPA test that estimates City mileage is the UR-1 scenario (minimum payload and no air conditioning). The UR-1 results averaged $55.6 \mathrm{mpg}$, or $3.6 \mathrm{mpg}$ better than the $52 \mathrm{mpg}$ EPA result. Overall, the Urban Loop mpg results ranged from 35.7 to $55.6 \mathrm{mpg}$ for the five-passenger Prius.

- The EPA highway test result for the Prius is 45 mpg. The FW-1 loop results, which are closest to the EPA test conditions, were slightly higher at $45.4 \mathrm{mph}$. The overall Freeway test results ranged from 40 to $45.4 \mathrm{mpg}$.

- With the exception of the UR-1 and FW-1 operating scenarios, the other six operating scenarios all place greater energy requirements on the Prius than the EPA testing scenarios, so the fuel use results are not unexpected.

- $\quad$ Overall, the Prius performed well in these initial tests and the ability to carry five passengers should be attractive for fleet applications.

- The testing did highlight that future range and fuel use testing should include test distances that are much longer than traditionally used for the Pomona Loop testing (and other testing) due to the stingy fuel use rates; great care should be taken to accurately measure fuel use.

- $\quad$ The planned Field Operations Program Accelerated Reliability testing should provide insight into any long-term operational issues that the Prius may have such as battery life.

- $\quad$ Future grid-connected HEVs may require testing in pure electric modes, which include collecting $\mathrm{kWh}$ energy use, in addition to collecting gasoline use rates. 

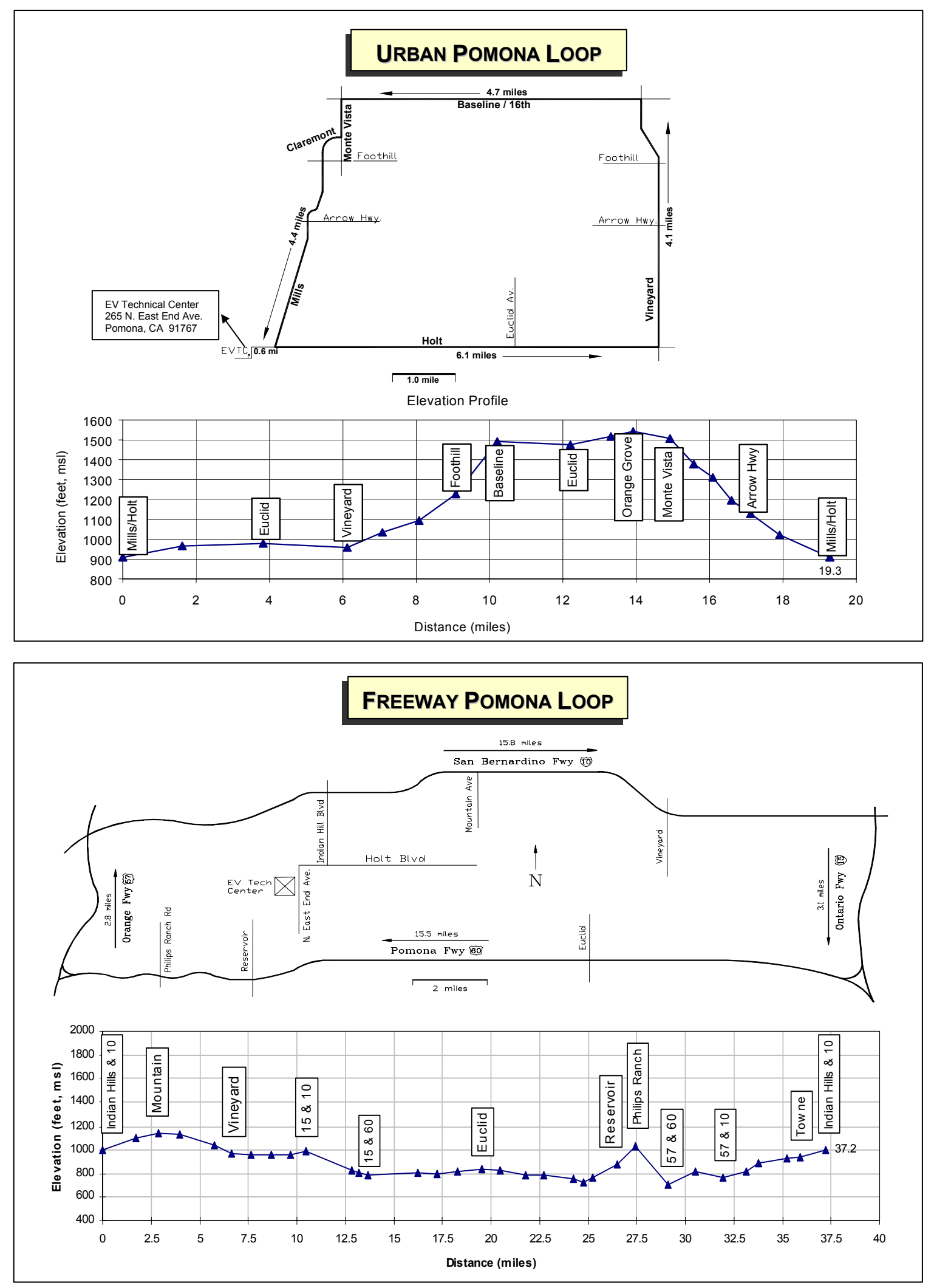